\title{
Sumberdaya Batuan Dan Pemanfaatannya Pada Beberapa Situs Megalitik Di Kawasan Jember
}

\section{Fadhlan S. Intan}

Keywords: geology, potential, megalithic, east java, distribution

\section{How to Cite:}

Intan, F. S. (2001). Sumberdaya Batuan Dan Pemanfaatannya Pada Beberapa Situs Megalitik Di Kawasan Jember. Berkala Arkeologi, 21(1), 30-41. https://doi.org/10.30883/jba.v21i1.831

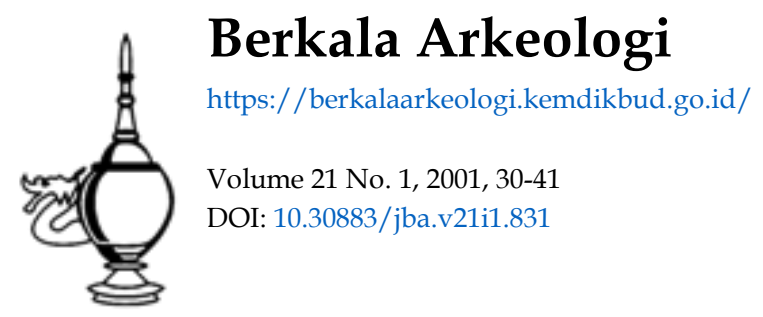

\section{c) (†)(2)}

This work is licensed under a Creative Commons Attribution-NonCommercial-ShareAlike 4.0 International License. 


\title{
SUMBERDAYA BATUAN DAN PEMANFAATANNYA PADA BEBERAPA SITUS MEGALITIK DI KAWASAN JEMBER
}

\author{
M. Fadhlan S. Intan \\ (Pusat Penelitian Arkeologi)
}

\section{PENDAhUluan}

Situs-situs megalitik di kawasan Jember, meliputi beberapa kecamatan, antara lain Kecamatan Sukowono, Kecamatan Sumber Jambe, Kecamatan Silo, Kecamatan Mayang, Kecamatan Arjasa, dan Kecamatan Jelbuk.

Situs-situs di wilayah Kecamatan Sukowono adalah Situs Sukosari (Dusun Sukosari. Desa Sukosari), dan Situs Sumber Pring (Dusun Sumber Pring, Desa Sukosari). Situssitus di wilayah Kecamatan Sumber Jambe adalah Situs Paleran (Dusun Paleran, Desa Gunung Malang), dan Situs Sumber Tengah (Dusun Sumber Tengah, Desa Randu Agung). Situs-situs di wilayah Kecamatan Silo adalah Situs Sumber Pakem (Dusun Sumber Pakem, Desa Silo). Situs-situs di Wilayah Kecamatan Mayang adalah situs Sumber Pakem (Dusun Sumber Pakem, Desa Seputih). Situs-situs di wilayah Kecamatan Arjasa adalah Situs Doplang (Dusun Doplang, Desa Kamal), Situs Situs Kebun Jurang (Dusun Kebun Jurang, Desa Kamal), Situs Kendal (Dusun Kendal, Desa Kamal), dan Situs Krajan (Dusun Krajan, Desa Kamal). Situs-situs di wilayah Kecamatan Jelbuk adalah Situs Lamparan (Dusun Lamparan, Desa Pandoman).

Situs-situs megalitik di kawasan Jember tercantum pada peta topografi (skala 1:50.000) Sheet No. 58/XLIII-A (Tamanan), untuk wilayah Kec. Sukowono dan Kec. Sumber Jambe, Sheet No. 58/XLIII-C (Soemberdjati), untuk wilayah Kec. Silo, Sheet No. 57/XLIII-D (Djember/Djember South) untuk wilayah Kec. Mayang, Sheet No. 57/XLIII-B (Djember/Djember North), untuk wilayah Kec. Arjasa dan Kec. Jelbuk.

\section{GEOLOGI SITUS MEGALITIK KAWASAN JEMBER}

Uraian tentang lingkungan geologi situs-situs megalitik kawasan Jember, ditekankan bentang alam, stratigrafi, struktur geologi, dan hidrogeologi.

\section{a. Geomorfologi}

Bentang alam (morfologi) situs-situs megalitik di kawasan Jember, di klasifikasikan berdasarkan Sistem Desaunettes, 1977 (Todd, 1980). Berdasarkan hal tersebut, maka situs-situs megalitik di kawasan Jember terbagi atas tiga satuan morfologi yaitu: 
ñ Satuan morfologi dataran (0-2\%), menempati area seluas $10 \%$, umumnya dimanfaatkan oleh penduduk sebagai wilayah pemukiman, dan lahan pertanian.

ñ Satuan morfologi bergelombang lemah (2-8\%), menempati area seluas $60 \%$, umumnya dimanfaatkan sebagai lahan pertanian, perkebunan, dan pemukiman.

ñ Satuan morfologi bergelombang kuat $8-16 \%$ ), menempati area seluas $30 \%$, umumnya dimanfaatkan sebagai lahan perkebunan.

Ketinggian Situs-Situs Megalitik di kawasan Jember, secara umum adalah 200 - 600 meter dpl, dengan curah hujan rata-rata $2000-2500 \mathrm{~mm} / \mathrm{tahun}$.

Pola pengeringan permukaan (surface drainage pattern) sungai-sungai di kawasan ini menunjukkan arah pengaliran ke segala penjuru, mengikuti bentuk morfologi kawasan Jember. Sungai induk yang mengalir di wilayah Kecamatan Sukowono dan Kecamatan Sumber Jambe adalah Kali Sumber Jambe, Kali Slateng, Kali Ajung, dan Kali Pringan dan beberapa anak sungai kecil (Kali Sat, Kali Sumber Tengah, Kali Besini, Kali Sumber Pring, Kali Sukosari, Kali Dawuhan, dll). Sungai-sungai induk ini umumnya berarah aliran timur-barat, sedang anak-anak sungai umumnya berarah aliran timur-barat, utara-selatan-barat, utara-selatan.

Sungai induk yang mengalir di wilayah Kecamatan Silo adalah Kali Silo. Kali Penjainan, Kali Merawan dan beberapa anak sungai kecil (Kali Sumber Pakem, Kali Sidomukti, dll). Sungai-sungai induk ini umumnya berarah aliran selatan-utara, sedang anak-anak sungai umumnya berarah aliran utara-selatan, barat daya-timur laut. Sungai induk yang mengalir di wilayah Kecamatan Mayang adalah Kali Mayang, Kali Merawan, dan beberapa anak sungai kecil (Kali Sumber Pakem, Kali Seputih, dll). Sungai-sungai induk ini umumnya berarah aliran timur laut ke barat daya, sedangkan anak-anak sungai umumnya berarah aliran baratdaya-utara, tenggara-utara. Sungai induk yang mengalir di wilayah Kecamatan Arjasa dan Kecamatah Jelbuk adalah Kali Kamal, Kali Biting, Kali Sugu, Kali Arjasa, dan beberapa anak sungai kecil (Kali Doplang, Kali Kebun Jurang, Kali Lamparan, Kali Krajan, Kali Pandoman, Kali Lamparan, dll). Sungai-sungai induk ini umumnya berarah aliran barat daya ke timur laut, sedangkan anak-anak sungai umumnya berarah aliran tenggara-baratlaut, timurbarat, dan barat-timur, utara-selatan, baratlaut-tenggara

Kelompok sungai-sungai ini (sungai induk dan anak-anak sungainya) pada pengamatan lapangan, termasuk pada kelompok sungai yang berstadia dewasa-tua (old-mature river stadium). Berpola pengeringan Dendritik dan Radial. Berdasarkan atas kuantitas air, maka sebagian dari sungai-sungai tersebut, termasuk pada sungai Normal/perenial (khusus untuk sungai-sungai induk), sungai Periodis/intermittent (khusus untuk sungai induk dan anak-anak sungai), dan sungai Episodis/epimeral (khusus untuk anak-anak sungai) (Lobeck, 1939; Thornbury, 1964). 


\section{b. Stratigrafi}

Penamaan satuan batuan yang menyusun situs-situs megalitik di kawasan Jember, didasarkan atas ciri lithologi, dan posisi stratigrafi. Atas dasar tersebut, maka satuan batuan yang menyusun kawasan situs ini adalah satuan batuan sedimen, satuan batuan beku, dan endapan aluvial.

Endapan Aluvial. Endapan aluvial terdiri dari bongkah, kerakal, lempung, lanau, dan pasir. Endapan aluvial tersebar luas di satuan morfologi dataran dan di sepanjang sungai. Endapan aluvial ini merupakan hasil pelapukan batuan penyusun wilayah Jember dan sekitarnya. Endapan aluvial ini berumur Holosen (10.000 tahun yang lalu).

Satuan Batuan Sedimen. Satuan batuan sedimen yang menyusun wilayah situs-situs megalitik Jember, berdasarkan atas hasil analisis petrologi adalah tufa dan breksi vulkanik.

Batuan tufa tersingkap di Situs Kebun Jurang, Situs Doplang (Desa Kamal, Kec. Arjasa), Kali Sumber Pakem (Desa Seputih, Kec. Mayang), di Gunung Sepikul (wilayah Dusun G. Sepikul, Desa Pakusari, Kec. Pakusari), tebing sebelah kanan jalan menuju Perkebunan Selosanen (atau lereng utara Gunung Selosanen). Kontak batuan antara tufa dengan andesit terlihat di Gunung Sepikul (wilayah Dusun G. Sepikul, Desa Pakusari, Kec. Pakusari). Kontak batuan antara tufa dengan dasit terlihat di tebing sebelah kanan jalan menuju Perkebunan Selosanen (atau lereng utara Gunung Selosanen).

Batuan breksi vulkanik tersingkap di Kali Sumber Pakem (Desa Seputih, Kec. Mayang), Sungai Sukosari (Desa Sukosari, Kec. Sukowono), Gunung Gumuk Kerang (Desa Karang Rejo, Kec. Sumbersari), Kali Sumber Pakem (Desa Seputih, Kec. Mayang), Situs-Situs Doplang, Kebun Jurang, Krajan, Kendal (wilayah Desa Kamal, Kec. Arjasa), Situs-Situs Sukosari, Sumber Pring (wilayah Desa Sukosari, Kec. Sukowono).

Penentuan umur satuan batuan sedimen (tufa dan breksi vulkanik) dilakukan dengan cara korelasi antar batuan yang didasarkan atas ciri-ciri litologi, kondisi daerah dan persebaran batuan serta memenuhi Prinsip Stratigrafi Indonesia. Berdasarkan hal tersebut, maka batuan tufa dapat disebandingkan dengan kelompok Tuf Argofuro dari Sapei, dkk (1992). Atas dasar kesebandingan batuan tersebut, maka batuan tufa berumur Plistosen Awal (?). Sedangkan breksi vulkanik dapat disebandingkan dengan kelompok Breksi Argopuro dari Sapei, dkk (1992). Atas dasar kesebandingan batuan tersebut, maka breksi vulkanik berumur Plistosen Tengah. 
Satuan Batuan Beku. Satuan batuan beku yang menyusun wilayah situs-situs megalitik Jember, berdasarkan atas hasil analisis petrologi adalah andesit, basal, dan dasit:

Kontak batuan antara andesit dengan tufa terlihat di Gunung Sepikul (wilayah Dusun G. Sepikul, Desa Pakusari, Kec. Pakusari). Batuan beku basal tersingkap di SitusSitus Paleran, Sumber Tengah (wilayah Desa Sukosari dan Gunung Kamal, Kec. Sumber Jambe), Situs-Situs Sukosari, Sumber Pring (wilayah Desa Sukosari, Kec. Sukowono), Situs-Situs Doplang, Kebun Jurang, Krajan, Kendal (wilayah Desa Kamal, Kec. Arjasa). Batuan beku dasit tersingkap di tebing sebelah kanan jalan menuju Perkebunan Selosanen (atau lereng utara Gunung Selosanen), yang merupakan kontak batuan antara dasit dengan tufa. Singkapan dasit tersebut merupakan pusat intrusi batuan beku dasit terhadap batuan penyusun wilayah Selosanen, yaitu batuan tufa.

Penentuan umur satuan batuan beku (andesit, basal, dan dasit) dilakukan dengan cara korelasi antar batuan yang didasarkan atas ciri-ciri litologi, kondisi daerah dan persebaran batuan serta memenuhi Prinsip Stratigrafi Indonesia. Berdasarkan hal tersebut, maka andesit dan basal dapat disebandingkan dengan Formasi Kali Baru dari Sapei, dkk (1992). Atas dasar kesebandingan batuan tersebut, maka batuan andesit dan basal berumur Plistosen Tengah. Sedangkan batuan dasit dapat disebandingkan dengan kelompok Batuan Terobosan dari Sapei, dkk (1992). Atas dasar kesebandingan batuan tersebut, maka breksi vulkanik berumur Miosen Tengah.

\section{c. Struktur Geologi}

Struktur geologi yang terdapat di Situs-Situs Megalitik di kawasan Jember adalah struktur sekunder (struktur epigenetik) dari jenis Kekar (joint). Kekar yang terdapat di wilayah situs ini, apabila diinterpretasikan berdasarkan atas genetiknya, maka kekar tersebut termasuk pada jenis kekar lembaran (sheet joint) dan kekar tiang (Columnar joint).

Kekar tiang (columnar joint) terlihat di Gunung Sepikul (wilayah Dusun G. Sepikul, Desa Pakusari, Kec. Pakusari), di tebing sebelah kanan jalan menuju Perkebunan Selosanen (atau lereng utara Gunung Selosanen), sedangkan kekar lembaran (sheet joint) terlihat di tebing sebelah kanan jalan menuju Perkebunan Selosanen (atau lereng utara Gunung Selosanen), di Gunung Sepikul (wilayah Dusun G. Sepikul, Desa Pakusari, Kec. Pakusari), dan di Gunung Gumuk Kerang (wilayah Dusun Pelindu, Desa Karang Rejo, Kec. Sumbersari). 


\section{d.Hidrogeologi}

Hidrogeologi situs megalitik di kawasan Jember, ditekankan kepada masalah airtanah dan produktivitas akifer (Poespowardoyo, 1981), sebagai berikut:

Kec. Sukowono, Kec. Mayang, dan Kec. Arjasa. Situs-situs di wilayah Kec. Mayang dan Kec. Arjasa, keterdapatan airtanah dan produktivitas akifer, adalah akifer dengan aliran melalui celahan dan ruang antar butir. Akifer produktif tinggi dengan penyebaran luas. Akifer dengan keterusan dan kisaran kedalaman muka airtanah sangat beragam dengan debit sumur umumnya lebih dari 5 liter/detik.

Kec. Sumber Jambe, Kec. Silo, dan Kec. Jelbuk. Situs-situs di wilayah Kec. Silo dan Kec. Jelbuk, keterdapatan airtanah dan produktivitas akifer, adalah akifer dengan aliran melalui celahan dan ruang antar butir. Akifer produktif sedang dengan penyebaran luas. Akifer dengan keterusan sangat beragam, kedalaman muka airtanah bebas umumnya dalam, dengan debit sumur umumnya kurang dari 5 liter/detik.

\section{TINGGALAN MEGALITIK DI KAWASAN JEMBER}

Tinggalan megalitik di kawasan Jember berbentuk pandusa, lesung, batu bergores, lumpang, dolmen, batu kenong, dan menhir. Tinggalan megalitik tersebut ditemukan di enam kecamatan yaitu Kec. Sukowono, Kec. Sumber Jambe, Kecamatan Silo, Kec. Mayang, Kec. Arjasa, dan Kec. Jelbuk.

\section{a. Kecamatan Sukowono}

Situs-situs megalitik di wilayah Kecamatan Silo, ditemukan di dua dusun yaitu Situs Sukosari termasuk wilayah Dusun Sukosari, Desa Sukosari, Kecamatan Sukowono, dengan temuan megalitik sebanyak 28 buah. Tinggalan arkeologi tersebut berbentuk dolmen terbuat dari batuan beku andesit dan basal, serta pandusa terbuat dari batuan beku andesit dan breksi vulkanik.

Situs Sumber Pring termasuk wilayah Dusun Sumber Pring, Desa Sukosari, Kecamatan Sukowono, dengan temuan megalitik sebanyak 22 buah. Tinggalan arkeologi tersebut berbentuk dolmen terbuat dari batuan beku andesit dan breksi vulkanik.

\section{b. Kecamatan Sumber Jambe}

Situs-situs megalitik di wilayah Kecamatan Sumber Jambe, ditemukan di dua dusun dan dua desa yaitu Situs Sumber Tengah termasuk wilayah Dusun Sumber Tengah, 
Desa Randu Agung, Kec. Sumber Jambe, dengan temuan megalitik sebanyak 16 buah. Tinggalan arkeologi tersebut berbentuk dolmen terbuat dari batuan beku andesit. Situs Paleran termasuk wilayah Dusun Paleran, Desa Gunung Malang, Kec. Sumber Jambe, dengan temuan megalitik sebanyak 10 buah. Tinggalan arkeologi tersebut berbentuk dolmen terbuat dari batuan beku andesit dan basal.

\section{c. Kecamatan Silo}

Situs-situs megalitik di wilayah Kecamatan Silo, ditemukan di satu dusun yaitu Situs Sumber Pakem termasuk wilayah Dusun Sumber Pakem, Desa Silo, Kecamatan Silo, dengan temuan megalitik sebanyak 9 buah. Tinggalan arkeologi tersebut berbentuk dolmen terbuat dari batuan beku andesit.

\section{d. Kecamatan Mayang}

Situs-situs megalitik di wilayah Kecamatan Mayang, ditemukan di satu dusun yaitu Situs Sumber Pakem termasuk wilayah Dusun Sumber Pakem, Desa Seputih, Kecamatan Mayang, dengan temuan megalitik sebanyak 6 buah. Tinggalan arkeologi tersebut berbentuk lesung terbuat dari batuan tufa, batu bergores terbuat berasal dari batuan Basal (batuan yang besar) dan andesit (batuan yang kecil). Sedangkan dolmen terbuat dari breksi vulkanik.

\section{e. Kecamatan Arjasa}

Situs-situs megalitik di wilayah Kecamatan Arjasa, ditemukan di empat Dusun yaitu Situs Doplang termasuk wilayah Dusun Doplang, Desa Kamal, Kecamatan Arjasa, dengan temuan megalitik sebanyak 114 buah. Tinggalan arkeologi tersebut hasil survei tahun 1997 adalah 114 , namun yang teramati pada tahun 2000 adalah 17 buah berbentuk batu kenong yang terbuat dari batuan beku andesit dan breksi vulkanik, dolmen terbuat dari batuan beku andesit dan breksi vulkanik, sedangkan menhir terbuat dari batuan beku andesit

Situs Kebun Jurang termasuk wilayah Dusun Kebun Jurang, Desa Kamal, Kecamatan Arjasa, dengan temuan megalitik sebanyak 17 buah. Tinggalan arkeologi tersebut berbentuk batu kenong, dolmen, lumpang terbuat dari batuan beku andesit. Sedangkan dolmen terbuat batuan beku andesit dan breksi vulkanik

Situs Kendal termasuk wilayah Dusun Kendal, Desa Kamal, Kecamatan Arjasa, dengan temuan megalitik sebanyak 25 buah. Tinggalan arkeologi tersebut berbentuk batu kenong dan dolmen terbuat dari batuan beku andesit. 
Situs Krajan termasuk wilayah Dusun Krajan, Desa Kamal, Kecamatan Arjasa, dengan temuan megalitik sebanyak 57 buah. Tinggalan arkeologi tersebut berbentuk batu kenong terbuat dari batuan beku andesit, basal, dan breksi vulkanik, dolmen terbuat dari batuan beku andesit, dan breksi vulkanik, sedangkan menhir terbuat dari breksi vulkanik.

\section{f. Kecamatan Jelbuk}

Situs-situs megalitik di wilayah Kecamatan Jelbuk, ditemukan di satu dusun yaitu: Situs Lamparan termasuk wilayah Dusun Lamparan, Desa Pandoman, Kecamatan Jelbuk, dengan temuan megalitik sebanyak 3 buah. Tinggalan arkeologi tersebut berbentuk Batu Kenong terbuat dari batuan beku andesit.

\section{PEMBAHASAN}

Dari hasil pengamatan lapangan yang didukung dengan analisis petrologi, maka aspek pemanfaatan batuan di beberapa situs megalitik di kawasan Jember dapat dibagi menjadi tiga pembahasan yaitu: a) Ada-tidaknya pengerjaan batuan yang dimanfaatkan sebagai tinggalan megalitik; b) Ada-tidaknya pemindahan boulder (bongkahan) batuan yang dimanfaatkan sebagai tinggalan megalitik dan; c) Lokasi sumber bahan baku batuan.

\section{a. Ada-tidaknya pengerjaan batuan}

Bentuk-bentuk tinggalan megalitik yang dijumpai di situs-situs tersebut adalah pandusa, batu kenong, menhir, dan lesung. Yang terbuat dari breksi vulkanik adalah pandusa, batu kenong, dan menhir. Yang terbuat dari batuan andesit adalah batu kenong, dan menhir. Yang terbuat dari basal adalah batu kenong, dan yang terbuat dari tufa adalah lesung. Dalam pemanfaatan batuan-batuan tersebut, ada yang dikerjakan dan ada pula yang tidak mengalami pengerjaan, sebagai berikut:

\section{$>$ Membutuhkan Pengerjaan}

Melihat ciri fisik dari setiap tinggalan (untuk semua jenis batuan yang dimanfaatkan) yang ternyata mengalami pengerjaan atau pemangkasan, yang kemudian dilakukan perbandingan dengan bentuk tinggalan yang ada, maka dapat dibuat suatu urutan pengerjaan yang didasarkan pada tingkat kesulitan dalam pembuatan tinggalan tersebut.

Berdasarkan hal tersebut diatas, maka yang menempati urutan pertama adalah yang mudah dikerjakan dan urutan terakhir adalah yang sulit dikerjakan, yaitu: 
- Tufa yang berbentuk lesung

- Andesit yang berbentuk batu bergores

- Andesit yang berbentuk menhir

- Andesit yang berbentuk lumpang

- Andesit, dan basal yang berbentuk batu kenong

- Andesit yang berbentuk batu kenong kembar

- Breksi vulkanik yang berbentuk pandusa

- Breksi vulkanik yang berbentuk menhir

- Breksi vulkanik yang berbentuk batu kenong.

Sebagai contoh, tinggalan megalitik yang mengalami pengerjaan adalah:

- Pandusa (breksi vulkanik) di Situs Sukosari (Dusun Sukosari, Desa Sukosari, Kec. Sukowono).

- Menhir (breksi vulkaanik) di Situs Kebun Jurang (Dusun Kebun Jurang, Desa Kamal, Kec. Arjasa)

- Lesung (tufa) di Situs Sumber Pakem (Dusun Sumber Pakem, Desa Seputih, Kec. Mayang)

- Lumpang (andesit) di Situs Kebun Jurang (Dusun Kebun Jurang, Desa Kamal, Kec. Arjasa).

- Menhir (andesit) di Situs Doplang (Dusun Doplang, Desa Kamal, Kec. Arjasa).

- Batu bergores (andesit) di Situs Sumber Pakem (Dusun Sumber Pakem, Desa Seputih, Kec. Mayang).

- Batu Kenong (breksi vulkanik) di Situs Doplang (Dusun Doplang, Desa Kamal, Kecamatan Arjasa); Situs Kebun Jurang (Dusun Kebun Jurang, Desa Kamal, Kec. Arjasa).

- Batu kenong (andesit) di Situs Doplang (Dusun Doplang, Desa Kamal, Kecamatan Arjasa); Situs Kebun Jurang (Dusun Kebun Jurang, Desa Kamal, Kec. Arjasa); Situs Lamparan (Dusun Lamparan, Desa Pandoman, Kecamatan Jelbuk).

- Batu kenong kembar (andesit) di Situs Doplang (Dusun Doplang, Desa Kamal, Kecamatan Arjasa); Situs Kebun Jurang (Dusun Kebun Jurang, Desa Kamal, Kec. Arjasa); Situs Kebun Jurang (Dusun Kebun Jurang, Desa Kamal, Kec. Arjasa).

- Batu kenong (basal) di Situs Kebun Jurang (Dusun Kebun Jurang, Desa Kamal, Kec. Arjasa).

\section{$>$ Tidak Membutuhkan Pengerjaan}

Selain itu, beberapa tinggalan megalitik berbentuk dolmen yang terbuat dari batuan andesit dan breksi vulkanik, dalam pengamatan ciri fisiknya, ternyata tidak dilakukan 
pengerjaan, bahan baku batuan yang tersedia dalam berbagai bentuk, langsung dimanfaatkan oleh masyarakat megalitik sebagai dolmen.

Sebagai contoh, tinggalan megalitik yang tidak mengalami pengerjaan adalah: Dolmen (breksi vulkanik) di Situs Sumber Pring (Dusun Sumber Pring, Desa Sukosari, Kec. Sukowono); Situs Sumber Pakem (Dusun Sumber Pakem, Desa Seputih, Kec. Mayang); Situs Kebun Jurang (Dusun Kebun Jurang, Desa Kamal, Kec. Arjasa); Situs Doplang (Dusun Doplang, Desa Kamal, Kecamatan Arjasa) dan; Situs Kebun Jurang, Dusun Kebun Jurang, Desa Kamal, Kec. Arjasa).

Dolmen (andesit) di Situs Doplang (Dusun Doplang, Desa Kamal, Kecamatan Arjasa); Situs Kebun Jurang (Dusun Kebun Jurang, Kec. Arjasa); Situs Kendal (Dusun Kendal, Desa Kamal, Kecamatan Arjasa) dan Situs Kebun Jurang, Dusun Kebun Jurang, Desa Kamal, Kec. Arjasa). Dolmen (basal) di Situs Sukosari (Dusun Sukosari, Desa Sukosari, Kec. Sukowono); Situs Paleran (Dusun Paleran, Desa Gunung Malang, Kec. Sumber Jambe) dan; Situs Sumber Pakem (Dusun Sumber

Pakem, Desa Seputih, Kec. Mayang). Menhir (breksi vulkanik) di Situs Kebun Jurang (Dusun Kebun Jurang, Desa Kamal, Kec. Arjasa).

\section{b. Ada-tidaknya pemindahan boulder (bongkahan) batuan}

Dari pengamatan lapangan terhadap tinggalan megalitik, didapatkan suatu data bahwa batuan-batuan yang digunakan sebagai dolmen, merupakan batuan yang insitu, artinya keberadaan batuan tersebut bukan hasil pemindahan manusia, tetapi keberadaan di tempatnya yang seperti terlihat saat penelitian, disebabkan oleh faktor alam.

Dolmen yang disebut dengan Batu Bergores yang terdapat di Situs Sumber Pakem, Dusun Sumber Pakem, Desa Seputih, Kec. Mayang, merupakan pengecualian, sebab di situs itu bongkahan-bongkahan batuan tidak ditemukan dalam jarak radius 100 meter persegi, akhirnya disimpulkan bahwa bongkah batuan bergores di ambil dari Kali Sumber Pakem yang berada pada jarak 100 meter ke arah timur. Di Kali Sumber Pakem banyak terdapat bongkahan-bongkahan batuan yang ukurannya sama atau lebih besar dari batu bergores.

Pandusa di Situs Sukosari (Dusun Sukosari, Desa Sukosari, Kec. Sukowono) yang terbuat dari breksi vulkanik dan telah mengalami pengerjaan, juga merupakan batuan yang insitu, artinya keberadaan bongkahan batuan itu adalah faktor alam, yang kemudian oleh masyarakat megalitik lalu dibuat menjadi pandusa.

Sedangkan tinggalan megalitik lain, berupa menhir, lesung, batu kenong tunggal dan kembar, yang terbuat dari berbagai macam batuan misalnya tufa, andesit, basal, dan breksi vulkanik, merupakan tinggalan yang tidak insitu, artinya, pengerjaan batuan 
untuk mendapatkan bentuk yang diinginkan dilakukan di tempat dimana batuan itu berada, setelah proses pengerjaan selesai, barulah tinggalan megalitik itu ditempatkan sesuai dengan keinginan masyarakat megalitik jaman dulu.

\section{c. Lokasi sumber bahan baku batuan}

Berbicara tentang lokasi sumber bahan, yang pertama kali dilakukan adalah mengamati jenis dan nama batuan (melalui analisis petrologi) dari setiap tinggalan megalitik, kemudian dibandingkan dengan batuan penyusun wilayah Jember, baik yang berbentuk singkapan batuan maupun boulder batuan.

Dari hasil pengamatan tersebut, dapatlah diuraikan lokasi-lokasi bahan baku batuan tersebut, sebagai berikut: Situs-situs di wilayah Kec. Sukowono (Sukosari dan Sumber Pring) dan situs-situs di wilayah Kec. Arjasa (Doplang, Kebun Jurang, Kendal, dan Krajan), tersusun oleh batuan beku andesit, basal, dan breksi vulkanik. Situs-situs di wilayah Kec. Sumber Jambe (Sumber Tengah dan Paleran), tersusun oleh batuan andesit dan basal, sedangkan situs-situs di wilayah Kec. Jelbuk (Lamparan), tersusun batuan andesit. Sehingga dapat dikatakan bahwa masyarakat megalitik di situs-situs tersebut, tidak mengalami kesulitan dalam membuat tinggalan-tinggalan megalitik, karena bahan baku yang melimpah.

Situs di wilayah Kec. Mayang (Sumber Pakem), tersusun oleh batuan tufa dan breksi vulkanik, sedangkan untuk batuan andesit dan basal merupakan hasil transportasi dari Gunung Sepikul dari arah barat daya melalui Kali Mayang. Dari data lapangan telah terlihat bahwa tinggalan megalitik dari jenis batuan andesit dan basal, ditemukan lebih sedikit dibanding dengan dengan tinggalan megalitik yang berasal dari jenis tufa dan breksi vulkanik.

Tinggalan megalitik di situs Sumber Pakem (Kec. Silo) terbuat dari batuan andesit. Ketersediaan batuan tersebut di situs ini, merupakan hasil transportasi dari dua lokasi. Lokasi pertama berasal dari arah sebelah barat situs, yaitu dari daerah Geraha dan Tegalragi yang tertransportasi melalui Kali Geraha. Lokasi kedua berasal dari arah sebelah timur laut yaitu Gunung Garaha melalui Kali Silo. 


\section{PENUTUP}

Berdasarkan uraian diatas, dapat disimpulkan bahwa kawasan Jember, merupakan suatu wilayah yang sangat tepat untuk dijadikan sebagai suatu lokasi pemukiman megalitik. Hal ini didukung dengan kondisi geologi yang secara umum sangat menunjang. Sumberdaya alam (batuan, air) yang melimpah, telah dimanfaatkan secara optimal oleh masyarakat megalitik di kawasan Jember. Masyarakat megalitik Jember telah menerapkan konsep adaptasi dalam mempertahankan kehidupannya.

Hal ini sesuai dengan konsep adaptasi yang disebutkan oleh Eriawati, (1997) yang menyatakan bahwa manusia dalam beradaptasi saling terkait dengan lingkungan. Keterkaitan itu sifatnya dinamis sehingga manusia secara terus menerus memodifikasi perilakunya yang terpilih agar dapat menjawab setiap tantangan yang ada, sehingga dapat menyesuaikan diri (adaptif) terhadap lingkungannya. Salah satu pilihan yang paling tepat untuk menjawab tantangan lingkungan itu adalah kemampuan teknologinya. Dengan teknologi manusia mampu bukan hanya menyesuaikan tetapi memodifikasi lingkungan sesuai dengan kebutuhan yang diperlukan. Berbagai proses yang memungkinkan manusia bertahan (survive) terhadap tantangan kondisi lingkungan membuktikan kemampuan manusia untuk beradaptasi. 


\section{KEPUSTAKAAN}

Bemmelen, R.W. van, 1949 The Geology of Indonesia. vol.IA, Martinus Nijhoff, The Hague.

Billing, M.P., 1972 Structural Geology. Prentice-Hall, Inc. Englewood Cliggs, New Jersey.

Dunbar O.C., \& Rodgers J., 1961 Principles of Stratigraphy. New York, John Wiley \& Sons, Inc.,4th printing, August, 1961.

Eriawati, dkk., 1997 Penelitian Sumberdaya Alam (Lingkungan Vegetasi) Di Situs Kompleks Gua Wilayah Maros, Sulsel. LPA Bid. Arkeometri, Puslit Arkenas.

Huang, Walter T. Phd, 1962 Petrology. McGraw-Hill Book Company.

Intan S. Fadhlan M., 1985 Penuntun Praktikum Petrologi. Jur. Teknik Geologi, Fak. Teknik, UNHAS (lingkungan terbatas).

Lobeck, A.K., 1939, Geomorphology, An Introduction To The Study of Landscape. Mc Graw Hill Book Company Inc, New York and London.

Pettijohn, P.J., 1975 Sedimentary Rocks. New York, Harper and Brothers.

Poespowardoyo, S.R., 1981 Peta Hidrogeologi Indonesia, Lembar XI Jember (Jawa). Dit.GTL, Ditjend Pertambum, Deptamben.

Prasetyo, B., dkk., 2000 Survei Lingkungan dan Sumber Bahan Baku Situs-Situs Megalitik di Wilayah Jember, Jawa Timur. Bidang Arkeometri, Pusat Arkeologi.

Sapei, T., dkk, 1992 Geologi Lembar Jember, Jawa. P3G, Ditjend. SDM, Deptemben.

Thornbury, W.D., 1964 Principle of Geomorphology. New York, London, John Willey and sons, inc.

Todd D.K., 1980 Groundwater Hidrology. John Willey \& Sons Inc, New York. 